\title{
Technology Transfer Models and Elements in the University-Industry Collaboration
}

\author{
Juan Jesus Arenas * (D) and Domingo González * \\ Engineering Department, Pontifical Catholic University of Peru, San Miguel Lima 32, Peru \\ * Correspondence: jjarenas@pucp.edu.pe (J.J.A.); dgonzal@pucp.edu.pe (D.G.)
}

Received: 1 February 2018; Accepted: 30 May 2018; Published: 6 June 2018

\begin{abstract}
Over the years, universities have been considered as research centers that seek to collaborate with industries to create innovative products. This link has generated many concepts, among them being the concept of technology transfer. The objective of this work is to present a systematic review on the technology transfer generated in university-industry collaboration (UIC). Based on a review of 66 papers, the results presented in this article include the technology transfer (TT) models presented in the literature, a description of the common elements in a transfer process, and a description of the interaction between the elements involved, through the presentation of a conceptual model of technology transfer in the context of collaboration between the university and the industry.
\end{abstract}

Keywords: technology transfer; model; mechanism; systematic review; technology transfer process

\section{Introduction}

Currently, national laws are promoting the link between science and industry through tax benefits or calls to access public funds. It should be noted that these measures serve to contribute to technology transfer (Bozeman 2000; Etzkowitz 2000; Klofsten et al. 2010; Sábato and Botana 1968; Shane 2004b). In the United States, with the creation of legislation for the patent procedure of universities and small enterprises in 1980 (called the University and Small Business Patent Procedures Act or Bayh-Dole Act), there was an increase in the interaction between science and industry, creating institutions that help to transfer technology, called technology transfer offices (TTO) (Siegel et al. 2003).

In Europe, national legislation to promote the process of technology transfer (TT) has been more recent. For example, in Germany, the equivalent of the Bayh-Dole Act occurred only 20 years later in 2002 (Grimpe and Fier 2010). As a result, legislation has promoted collaboration between universities and industry (called university-industry collaboration or UIC (Mascarenhas et al. 2018; Vick and Robertson 2017)) and with it university TTOs have emerged, leading to growing patent registration and improvements in this complex process in technological and organizational terms (Anderson et al. 2007). It should be noted that universities have experience in TT processes due to active interactions with industry; however, its mechanisms end up being informal with poor administration as researchers have few management skills in the transfer process.

The process of technology transfer, which aims to bring research to an industrial product, is an important point of innovation (Cohen et al. 2002). It is necessary to close the gaps between research and commercialization to generate competitiveness in the industry (Nilsson et al. 2010). In the particular case of university-industry collaboration (UIC), it can be seen that the two agents are clear about the need to close these gaps and through them the process of technological transference arose. Furthermore, universities have an objective (third mission) to support the innovation of the industry through the creation of technological developments and research that are useful for commercialization and competitiveness (Etzkowitz and Ranga 2013). 
TT is a very complex subject as there are many elements, social factors, and different mechanisms involved during the process of the migration of university technology towards industry use (Bozeman 2000; Perkmann et al. 2013; Siegel et al. 2004). Considering this complexity, in addition to the increase of papers on the topic that has been seen in recent years (Figure 1), there is a great need to review the literature to find common behaviors that help to simplify the understanding of technology transfer in the context of collaboration between universities and the industry.

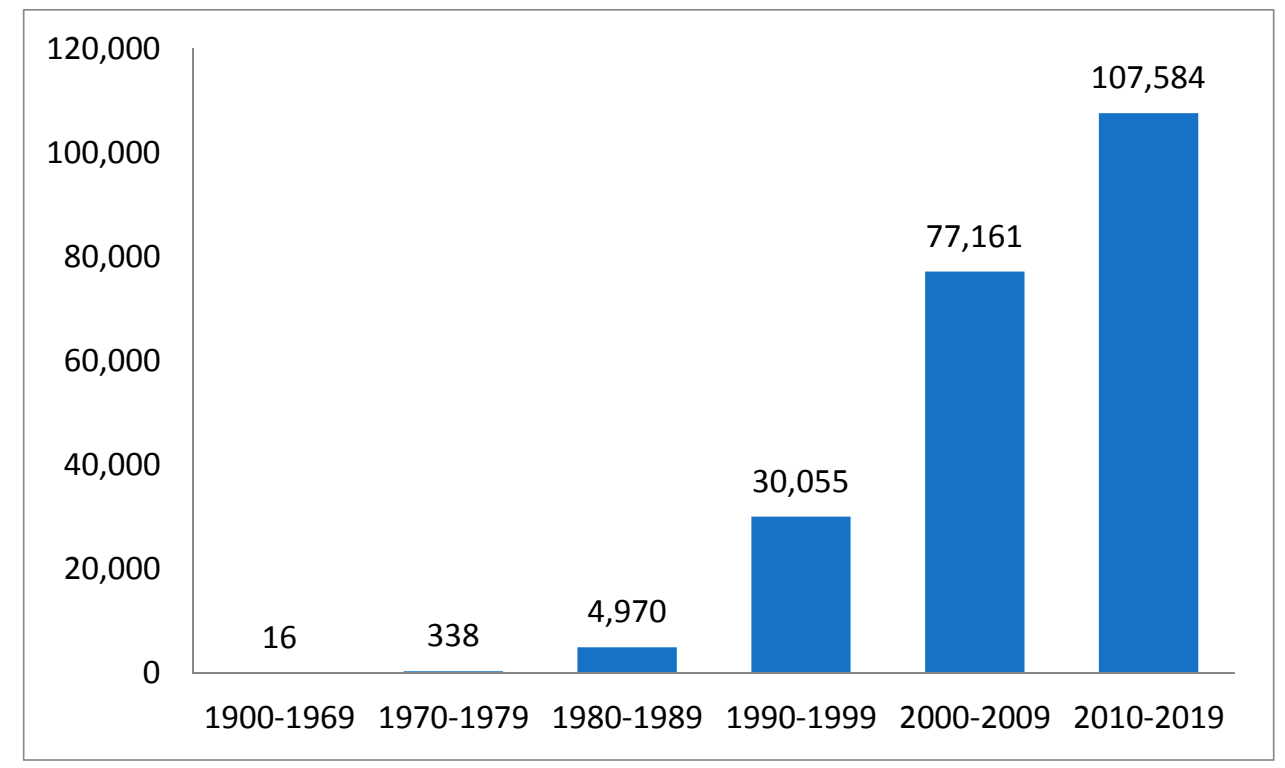

Figure 1. Technology transfer term frequency in PROQUEST.

The aforementioned complexity and the large amount of literature that can be found on this subject make it necessary to discuss different models of technology transfer, to present and understand the elements involved, and to identify the relationship of technology transfer in the collaboration between universities and industries.

In this literature review we tried to identify different models, elements, mechanisms, and factors of different cases. The primary objective of this review was to identify and improve our understanding of the common elements that occur in different models of technological transfer in university-industry collaboration. To achieve this goal, the following activities were proposed: (1) Identify and present the models found in the literature. In this part we present the model and its main characteristics. (2) Identify and present the common elements in a TT process. In this part we present the elements of a common transfer process and then present elements that appear in the context of UIC. (3) Present the interaction between the elements within the UIC context. In this part we present each description of the elements and then present how they interact with each other, developing a conceptual model that furthers the understanding of this activity.

It should be noted that the term technology transfer has evolved to encompass a new term, namely "knowledge transfer" (Cunningham et al. 2017). However, this research is limited to the process of marketing a technology (also called technology transfer) and not to the interactions that exist in the transfer process (knowledge transfer) (Miller et al. 2016).

Our paper is organized as follows. In Section 2, we describe the technological transfer as a model. In Section 3, we discuss about the methodology followed in the systematic review of the literature, and in Section 4, we present the findings. We conclude the paper with a discussion of our findings and possible future work. 


\section{Conceptual Background-Technological Transfer as Model}

Before executing the SRL, it is necessary to define the concept of the TT model in the context of UIC. In this section we present the definition of the TT model and its interactions with external factors. This chapter is necessary to understand the selection of SRL keywords, the results presented, and the conceptual model that is defined by the results.

TT, from the point of view of a model, involves key elements, processes, behaviors, and social factors (Heslop et al. 2001). Landau, Maddock, Shoemaker, and Costello (Landau et al. 1982) pointed out the need to see TT as a model that has a logical structure, where the key elements are the user who acquires the technology, the content of the package, the technology to be transferred (within the form of a technology transfer), and marketing or promotion.

It is necessary to conceive of the implementation of TT as a complex process (Spencer 1990) in which all activities must be related in parallel. In addition, it is necessary to understand that social and behavioral factors influence the successful development of the TT process (Choi 2009; Galbraith et al. 2006; Heslop et al. 2001; Lulu et al. 1996; Pereira Fialho and Alberton de Lima 2005; Purushotham et al. 2013; Waroonkun and Stewart 2008).

External factors, also known as environment factors, are also central to a TT model. In this instance, they are social or behavioral factors. Thus, authors like Bozeman (Bozeman 2000; Bozeman et al. 2015) call them the criteria of effectiveness, and Malik (2002) described them as factors of influence, to highlight a few examples. Social or behavioral factors influence each agent differently (Khabiri et al. 2012; Waroonkun and Stewart 2008). This influence is manifested many times by the education, training, or confidence that the agents have obtained of the technology to transfer (Choi 2009). Other important factors included in TT models are the level of technology (Hoffmann et al. 2009; Landry and Amara 2012; Landry et al. 2013), the protection of the technology transferred (Rahal and Rabelo 2006), as well as the promotion, marketing, and the marketing method (Heslop et al. 2001; Landau et al. 1982). For the particular case of the collaboration of a university with an industry, Perkmann (Perkmann et al. 2013) considered that the collaboration depended on the "organizational context", where depending on the work environment of the researchers, they will feel more or less motivated to collaborate with the industry.

\section{Research Design of the Literature Review}

The systematic review of literature (SRL) aimed to identify the current status of a subject in knowledge. For the present paper, we wanted to know the current knowledge on the processes, elements, and important factors of technological transfer that occur in the collaboration between a university and industry. In order to achieve this goal, it was proposed to follow the planning and implementation of the review presented by Tranfield (Tranfield et al. 2003). An SRL is divided into two stages. The first refers to planning and is responsible for defining the scope and limitations of the literature review. In this stage you must define the criteria for articles to be included in the search. It is also necessary to define the exclusion criteria, which will help to better focus the results presented. Figure 2 shows the steps that were followed to select and conduct the systematic review. The first four steps were used to plan the investigation and the last step, the revision of the complete text of the papers, refers to the conduct of the systematic review of literature. 


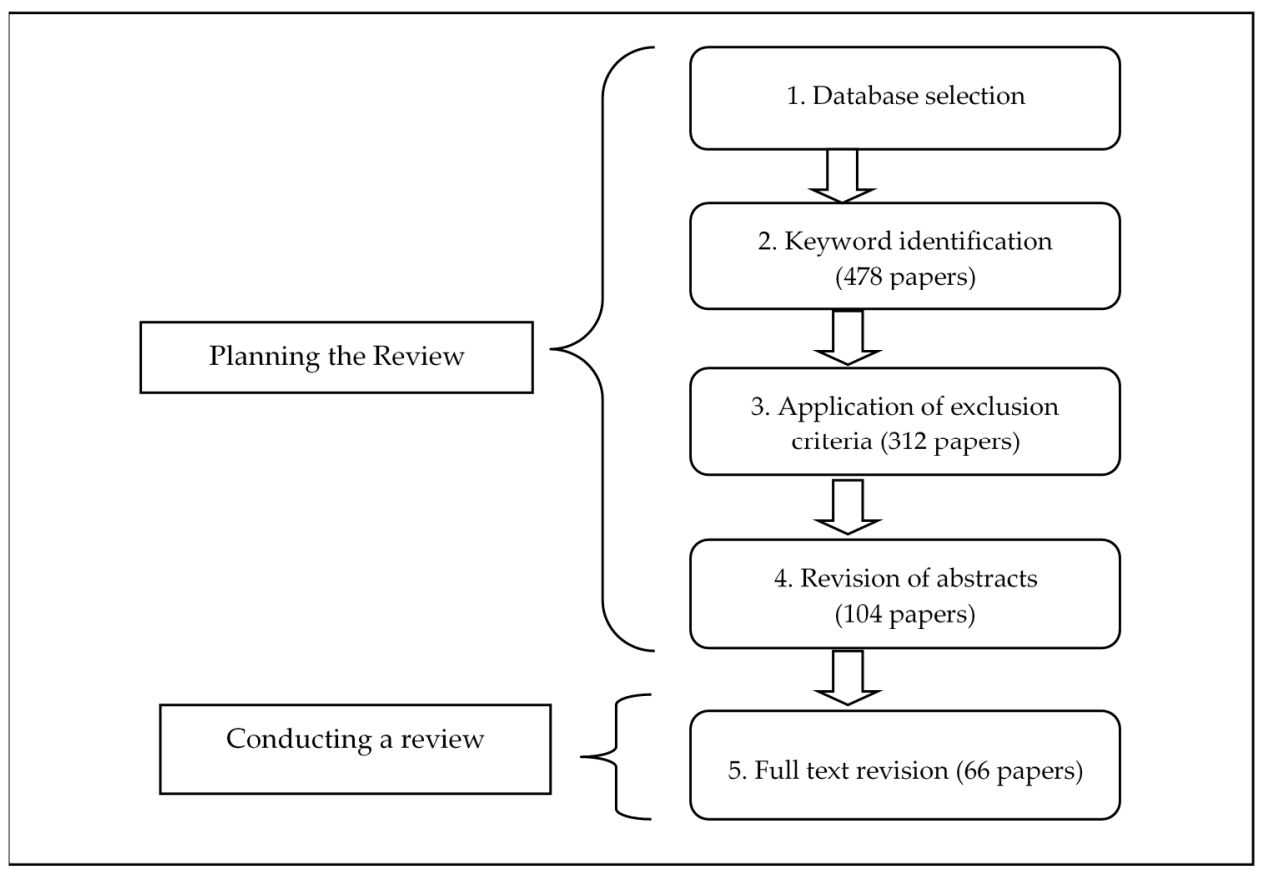

Figure 2. Systematic review process.

As a first step, it is necessary to define the objectives of the systematic review of the literature. For this paper, the objective was to identify the models, elements, and determining factors of the technological transfer. This paper focused on the information technologies that were the product of collaborations between universities and industries.

Then, as a second step it is necessary to center the scope of the search. The papers were selected from the EBSCO, Emerald, ProQuest, IEEE, and Science Direct databases as well as the digital library of the Latin-Ibero-American Association of Technology Management (ALTEC). The selection of ALTEC was made as it has an interesting repository on innovation and technology transfer in Latin America. Regarding the identification of keywords, it was decided that they must contain the terms technology transfer and, university, industry, company, or government. Then, all of the papers were filtered to ensure that they contained in the abstract the words mechanism, strategy, model, marketing, or policies. In this step, the number of papers found was 478 .

In the third step of the paper selection process, the exclusion criteria were applied. The first criterion of exclusion was the year of publication. We only considered information from 1980 onwards (Ohara 1981; Smits 1984) as since that year a much greater interest in the subject of UIC arose-a clear example of which is the creation of the Bayh-Dole law. The second exclusion criterion was the interest in topics related to information technologies, which excluded topics related to agriculture, fishery, and biomedicine. These sectors were excluded as they have different transfer models, not only at the university level with the industry, but also between the research institutes, which could distort the literature on technology transfer in collaborations between universities and companies. In this step, the number of papers found was 312 .

For steps 4 and 5, tags were used in the papers read, which helped to identify whether or not the paper should be excluded. These tags were divided into two types: actors (industry, university, or government), and action (strategy, mechanism, marketing, model, or policy). For actions, commercialization was not considered, as the extensive literature that exists in this area could distort the different elements involved in the process of technological transfer. The first label, actors, served to determine if the papers contributed in the literature on issues related to university-industry collaboration; and the second label, action, determined whether the paper studied any action relevant to the investigation. In sum, items that did not have any of these tags were excluded from the list. As 
a result of the process, 66 papers, 48 scientific papers, 16 ALTEC conferences, and two books were selected, which were interestingly distributed.

Due to the amplitude of articles on the topic of technological transfer, this paper is unable to cover several concepts. It is necessary to note that this paper does not take into account the absorption capacity; neither does it go into detail about the level of technology that will be delivered to the agent.

\section{Results}

Figure 3 shows the evolution of papers published between 1982 and 2015. A very homogeneous distribution was observed, showing increases in the years 2001, 2011, 2013, and 2014. Of the 50 papers found, it is shown that eight were published in the Journal of Technology Transfer. The rest of the papers were published in other journals, such as Technovation, Research Policy, and Research Technology Management.

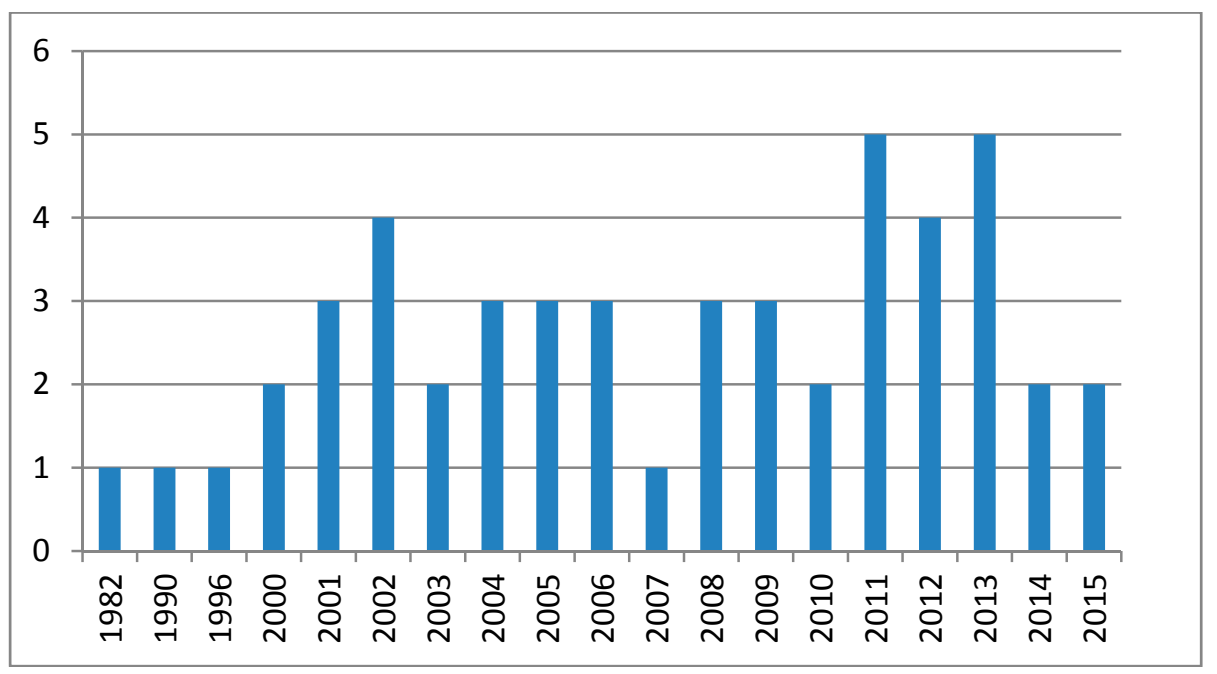

Figure 3. Number of papers per year.

In the case of Latin America, the evolution of issues related to technology transfer in the context of the collaboration between universities and industries has also grown. Figure 4 shows the increase in papers presented at the ALTEC congress during the past years.

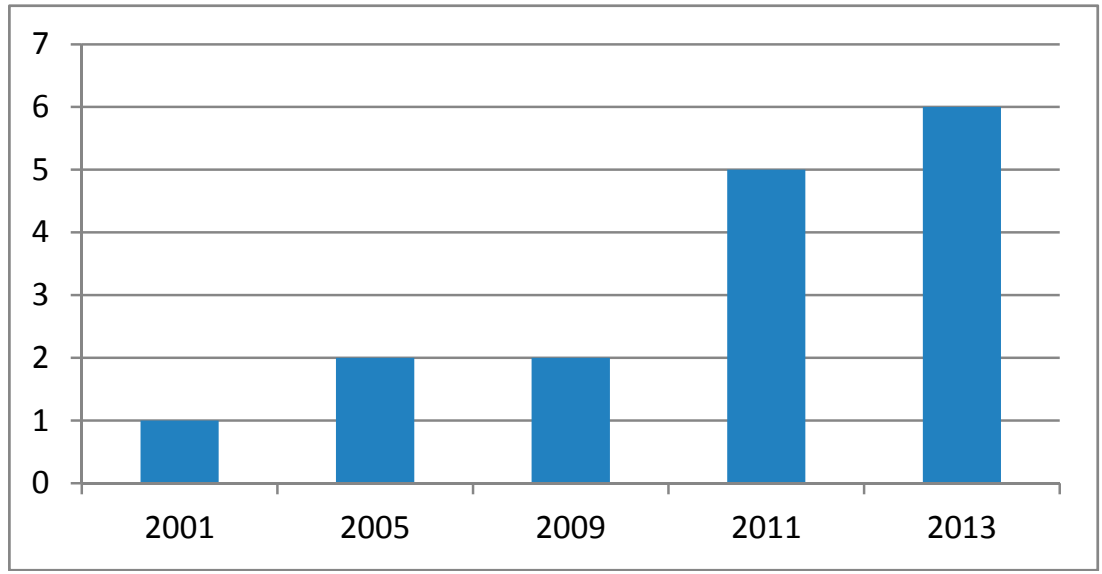

Figure 4. Number of papers presented at Latin-Ibero-American Association of Technology Management (ALTEC). 
In general, there has been a continuity of publications since 2000, with the term university-industry collaboration being the most used. On the other hand, there are many issues related to startups, so there have been studies that indicate that entrepreneurship is a technology transfer modality.

\section{Discussion}

Concerning the content found in the papers, the findings can be divided into three groups. The first refers to papers that present models of technological transfer. This list consists of 10 papers and is characterized by models based on one or several experiences of technology transfer in the context of collaboration between universities and industries. The second group of findings is characterized by case studies where the authors present their experiences in transferring a technology. Although these papers do not present a model, it is possible to describe the elements that are necessary to transfer a technology. This group describes the basic elements that must exist in a TT. Although each author describes it in a different way, they have the same definition. It should be noted that in this group a contribution is made in the division of transfer modalities and a mapping between the state of technology and the transfer mechanism. The third group of findings presents the complementary elements in TT for the UIC context. These elements are not fundamental to the transfer models; however, they are very helpful for the transfer process to be carried out in the best way.

\subsection{Approaches to Technology Transfer Models}

With respect to the first group of findings, a prime example is the work of Bozeman, who presented the "Contingent Effectiveness Technology Transfer Model". This model highlighted two important components: first, the determinants of effectiveness, which are those elements that help a transfer be effective; and second, the criteria to generate effectiveness in the TT, which make up the process environment (Bozeman 2000; Bozeman et al. 2015).

On the other hand, Malik (2002) described a TT model as something basic, as it is a process of communication. The model considers a sender, a message, and a receiver. The same distribution of elements can be found in the models of Bozeman (Bozeman 2000; Bozeman et al. 2015), Rubiralta (2004), and Choi (2009). It should be noted that these authors presented their models based on the triple helix (Etzkowitz 2000). Furthermore, Mayer and Blaas (2002) presented models of TT for different situations in European countries where they placed the university as an emitter, the industry as a receiver, and the transferred technology as the message. Although agents are repeated in all models, the communication process (also called mechanism) differs greatly from the TT process. It is necessary to emphasize that a TT process differs in some subjects; for example, the receiver can often become the sender and vice versa for a single transfer. In the specific case of the collaboration between a university and an industry, there is a process of validation and learning that is cyclical (Burnside and Witkin 2008; Gorschek et al. 2006). Taking into account the Malik (2002) model, the "message" - which for the TT process is technology, scientific knowledge, or any research result — can be presented in different ways (the presentation is also known as the transfer medium) and the transfer process can be performed by different mechanisms, which are known as transfer mechanisms (Heinzl et al. 2013). It should be noted that authors such as Bozeman (Bozeman 2000; Bozeman et al. 2015), Rubiralta (2004), Malik (2002), Waroonkun and Stewart (2008), and Khabiri (Khabiri et al. 2012) did not differentiate between the medium and mechanism for the TT processes. However, other authors such as Landau (Landau et al. 1982) (who separated the middle element of the package from the marketing mechanism), Mayer and Blaas (2002) (who separated what the university sends and what the industry receives), and Hoffmann (Hoffmann et al. 2009) (for whom, according to the level of the object, the university used a different medium and the transfer was performed in a different mechanism) differentiated the mediums from the mechanisms.

The models presented by Mayer and Blaas (2002), Rubiralta (2004), and Kalnins and Jarohnovich (2015) emphasized the presence of an intermediary because the "emitter" of technology has different objectives, policies, and behaviors than the receiver. This new agent (later called the technology 
transfer office) has the role of translating the "messages" sent by both the university and industry (Lai 2011; Landry and Amara 2012; Mesquita and Popescu 2014). It is appreciated that the models have common elements, which will be described below. Table 1 presents a summary of the models found in the literature, where the methodology used for each paper to present the models of technology transfer is highlighted.

Table 1. List of models of technology transfer (TT).

\begin{tabular}{|c|c|c|c|c|}
\hline Year & Author & Range & Key Factors of the Model & Methodology \\
\hline 1982 & Landau & $\begin{array}{l}\text { General model of } \\
\text { technology transfer }\end{array}$ & $\begin{array}{l}\text { The model is focused on the transmission of } \\
\text { information. } \\
\text { The model considers the promotion of the } \\
\text { product as a main factor for the delivery of the } \\
\text { product. }\end{array}$ & $\begin{array}{l}\text { Qualitative } \\
\text { (practical case) }\end{array}$ \\
\hline 2002 & Malik & $\begin{array}{l}\text { Between areas of a } \\
\text { company }\end{array}$ & $\begin{array}{l}\text { Based on the broadcasting process. } \\
\text { The model is presented for agents of the same } \\
\text { institution. } \\
\text { The model describes positive and negative } \\
\text { factors that influence the transfer process. }\end{array}$ & $\begin{array}{l}\text { Qualitative } \\
\text { (conceptual model) }\end{array}$ \\
\hline 2002 & $\begin{array}{l}\text { Mayer and } \\
\text { Blass }\end{array}$ & University-industry & $\begin{array}{l}\text { The model presents different approaches that } \\
\text { can be used depending on the characteristics of } \\
\text { the agents. } \\
\text { The model describes the importance of a new } \\
\text { actor that allows for "translating" the language } \\
\text { spoken by the transmitter and receiver. }\end{array}$ & $\begin{array}{l}\text { Qualitative } \\
\text { (practical case) }\end{array}$ \\
\hline 2004 & Rubiralta & University-industry & $\begin{array}{l}\text { The model presents a system approach based } \\
\text { on the triple helix, where the main agents are } \\
\text { the university, as a creator of technology, the } \\
\text { industry, as a receiver of technology, and the } \\
\text { technology transfer office (TTO), as the } \\
\text { intermediary agent that supports the transfer } \\
\text { process. }\end{array}$ & $\begin{array}{l}\text { Qualitative } \\
\text { (conceptual model) }\end{array}$ \\
\hline 2006 & $\begin{array}{l}\text { Gorschek, } \\
\text { Garre, } \\
\text { Larsson, } \\
\text { and Wohlin }\end{array}$ & University-industry & $\begin{array}{l}\text { It is a model built from a particular case. } \\
\text { Describes seven steps that should be taken to } \\
\text { achieve technology transfer. }\end{array}$ & $\begin{array}{l}\text { Qualitative } \\
\text { (practical case) }\end{array}$ \\
\hline 2008 & $\begin{array}{l}\text { Waroonkun } \\
\text { and Stewart }\end{array}$ & $\begin{array}{l}\text { Between international } \\
\text { industries }\end{array}$ & $\begin{array}{l}\text { The model considers that the transfer process is } \\
\text { influenced by the political and social } \\
\text { environment. } \\
\text { The model also describes the importance of } \\
\text { learning from past experiences for future } \\
\text { technology transfer processes. }\end{array}$ & Quantitative \\
\hline 2009 & $\begin{array}{l}\text { Hoffmann, } \\
\text { Amal and } \\
\text { Mais }\end{array}$ & University-company & $\begin{array}{l}\text { The model describes that there are three levels } \\
\text { that university research can offer: level of } \\
\text { science, level of technology, and level of use. } \\
\text { The transfer can occur at any level. }\end{array}$ & $\begin{array}{l}\text { Qualitative } \\
\text { (practical case) }\end{array}$ \\
\hline 2012 & $\begin{array}{l}\text { Khabiri, } \\
\text { Rast and } \\
\text { Senin }\end{array}$ & $\begin{array}{l}\text { Between areas of a } \\
\text { company }\end{array}$ & $\begin{array}{l}\text { It is a model based on the model presented by } \\
\text { Malik (Malik 2002), where the "great } \\
\text { environment" is added; that is, the legislative } \\
\text { environment that influences technology } \\
\text { transfer. }\end{array}$ & $\begin{array}{l}\text { Qualitative } \\
\text { (conceptual model) }\end{array}$ \\
\hline 2015 & $\begin{array}{l}\text { Bozeman, } \\
\text { Rimes and } \\
\text { Youtie }\end{array}$ & $\begin{array}{l}\text { General model of } \\
\text { technology transfer }\end{array}$ & $\begin{array}{l}\text { The model considers criteria of effectiveness as } \\
\text { a fundamental factor for the transfer process. } \\
\text { In the update of the model presented in } 2015 \text {, } \\
\text { the value of the public was added as a factor } \\
\text { that determines the success of a transfer. }\end{array}$ & $\begin{array}{l}\text { Qualitative } \\
\text { (conceptual model) }\end{array}$ \\
\hline 2015 & $\begin{array}{l}\text { Kalnins and } \\
\text { Jarohnovich }\end{array}$ & University-industry & $\begin{array}{l}\text { The model describes that there is not only } \\
\text { formal technological transfer, but also informal } \\
\text { technological transfer. } \\
\text { The model is based on the fact that the } \\
\text { university currently has the mission of helping } \\
\text { the industry generate innovation. }\end{array}$ & $\begin{array}{l}\text { Qualitative } \\
\text { (conceptual model) }\end{array}$ \\
\hline
\end{tabular}

\subsection{Traditional Elements for Technology Transfer}

Of the traditional elements of a technology transfer, it can be described that there is the transmitter (donor or sender), receiver (transferee), transfer object, and mechanisms. In the case of the mechanism, it can be seen that there is a discussion among the authors about the mechanisms and mediums. We are going to finish this section by presenting a table that helps to map all the elements described, with 
the separation of mechanisms and mediums, and then we will present a conceptual model where the interaction of the elements described above can be appreciated.

\subsubsection{Transmitter, Sender, or Donor Agent}

This first traditional element is one that develops the technology in laboratories; for example, the university can be considered as a transmitter. Bozeman (Bozeman 2000; Bozeman et al. 2015) described the transmitter as the person in charge of creating a technology (transferred object) to transfer it to the receiving agent. This transfer is done through a mechanism: patents, licenses, exchange of personnel, etc. On the other hand, authors such as Malik (2002), on the basis of the communication model, recognized the transmitting agent as the sender and Waroonkun and Stewart (2008) described it as a transferor or donor of technology.

It should be noted that a university does not only generate education, since it is known that one of its main objectives is to support society in issues of technology generation. The university understands that it has laboratories that surely industry does not have and that if it does not help, it will not be possible to generate new technologies that in the long run could become innovations (Sætre et al. 2009). Furthermore, the university can help small and medium-sized enterprises (SMEs), by acting as their R\&D (Research and Development) area so that, in the long term, these industries may grow and seek to invest in more research. Although there are many benefits to university-industry ties, universities must learn to work at the pace of the industry, that is, in times and milestones (Rahmany et al. 2013), and to carry out specific and not necessarily fundamental research. For example, the United States government in the 19th and 20th centuries was dedicated to solving problems relating to agriculture, public health, and industry (Mowery 2011).

Currently, universities are generating measurable research, which can be published in a journal or presented at a conference (Landry et al. 2013); many of these are patented and could be transferred to the industry. The technology patented by a university can be offered to the industry through a license or it can also be offered through a spin-off (Carrick 2014). This latter method of transfer is very appreciated in academic entrepreneurship (Djokovic and Souitaris 2008; Shane 2004a).

On the other hand, the mediums of transference that universities share with industries are not only formal (patents or licenses); there are also informal transfers, which are more common. Thus, informal transfers such as the recruitment of a recent graduate or the reading of scientific publications are more frequent than the licensing of patents (Hughes and Kitson 2012). Although the recruitment of graduates or the reading of scientific publications do not have the main purpose of transferring technology, the link with this medium allows industries to market technology developed in a university.

It is necessary to highlight that the research carried out by a university can be transferred from basic and applied research. This can be seen in research related to engineering and science (Hughes and Kitson 2012). This reality of the transfer of basic and applied research occurs because the university investigates issues of importance to the industry within its society (Dai et al. 2005). Nilsson, Rickne, and Bengtsson (Nilsson et al. 2010) reaffirmed the study and presented a classification of the reasons why a researcher transfers their knowledge to a given industry, indicating that the environment (society, transfer office, companies, and industry) is fundamental to the commercialization of technology.

\subsubsection{Receiver or Transferee Agent}

The receiver is the element that receives the technology and is in charge of taking advantage of it to generate innovation. Bozeman (Bozeman 2000; Bozeman et al. 2015) described this element as the receiving agent; Malik (2002) as the receiver; and Waroonkun and Stewart (2008) as the transferee.

Unlike universities, industry has the objective of profitability (Brennan and Turnbull 2002) and for this, the industry looks for technologies that generate this benefit. In this way, the industry will always look for technologies that generate value, and UIC helps to achieve this purpose (Fialho and Alberton de Lima 2001). This is why collaboration not only occurs when universities 
offer a technology, but also when the industry seeks to contribute to the creation of new technologies or industries. The industry considers open innovation as part of its strategy and seeks to collaborate with universities (Dalmarco et al. 2015). For example, we present the case studied by Sætre (Sætre et al. 2009), in which a Norwegian industry, which had contact with a university, sought out technology to generate an intelligent engine.

It should be noted that the size of the industry does not matter for collaboration with a university. Although size does not matter for collaboration, the industry must have experience in managing projects (Okamuro and Nishimura 2013), as university researchers lack the management skills (Fialho and Alberton de Lima 2001) or do not have time to perform such projects (Perez et al. 2011). It is also important for the industry to understand how a university transfers its technology (Landry et al. 2013) and to have experience in managing new technologies (Sætre et al. 2009).

\subsubsection{The "Message" or Object}

Another important element, which is presented by the authors, is the technology itself. Some models present the technology under different names. For example, Malik (2002) presents it as "the message" that will be sent from the sender to the receiver and Bozeman (2000) knows it as "the object" that must be transferred during the TT process.

In the UIC context, the object is treated in different ways by the agents. The industry sees the object from a perspective of the state of use of the technology, that is: exploration, validation, or exploitation (Landry et al. 2013). The industry not only acquires technologies for exploitation, it also acquires technologies that can explore or validate new knowledge. The industry seeks technologies that generate, at some point, a value and are aligned with the objectives of the industry (Van den Berghe and Guild 2008). In the case of a university, as a transmitter, the object developed and ready to be transferred is found in three levels: science, technology, and use (Hoffmann et al. 2009). The university not only transmits technology ready for use, but also technology that is at the science or technology levels (Agrawal and Cockburn 2003).

These differences of perspective of the object, according to both universities and industries, indicate that there are several modes of transfer (Dutrénit et al. 2010). On the one hand, we have the formal modalities, which have as a main objective the generation of a clear transfer process. Among the main media in this mode we have patents and prototypes (Hughes and Kitson 2012). On the other hand, we have the informal modalities, which are not intended to generate a transfer process but the process still exists. Among the main mediums we have the presentation of conferences and contraction of investigation personnel (Agrawal and Cockburn 2003; Khakbaz 2012).

In conclusion, the industry does not make reference to the level at which the technology is in the university, which is the reason why the object can be transferred at any level. The industry will only use the technology that helps its strategy, generates a competitive advantage, or generates innovation, regardless of the state of the technology transferred.

\subsubsection{Mediums and Transfer Mechanisms}

In the literature there is a disagreement about these elements. Some authors do not present differences in mediums and mechanisms (Bozeman 2000; Malik 2002; Rubiralta 2004) while other authors do present these elements in different ways (Hoffmann et al. 2009; Kalnins and Jarohnovich 2015). The mechanism refers to the tool that allows the object (technology) to be transferred, while the medium is the form of presentation of the object.

Within the literature another element related to the mechanisms and mediums can also be found, which is called the modality. In the literature, two modalities are described: the formal modality, whose objective is to present and try to transfer the technology developed, and the informal modality, whose objective is not to transfer technology but to present the "object" as an interest group and in the process to generate a technological transfer (Kalnins and Jarohnovich 2015; Mayer and Blaas 2002). It should be noted that the mechanisms and mediums used depend on the motivations and barriers 
which are consequences of the social and political factors that arise in the collaboration between agents (Vick and Robertson 2017).

Table 2 shows the interaction between the objects and the mediums, mechanisms, and modalities. It should be noted that the objects to be transferred can be presented by different mediums (Cohen et al. 2002) and could use different transfer mechanisms. In the case of modality, informal and formal ones are considered. A difference at the level of mechanisms and mediums can be observed. There is only one mechanism that can be used by the two modalities, namely university spin-off, which also a relationship with university entrepreneurship (Grimaldi et al. 2011; Perkmann et al. 2013; Rothaermel et al. 2007). In the case of the exit, it can be seen that there is the use of technology and the creation of companies, with or without legal restrictions. It is necessary to highlight that the literature shows the concept of transferred knowledge, which aids in understanding the link between technology transfer and knowledge transfer at the output level in the technology transfer process. The Table 2 was prepared on the basis of the papers of Bozeman (2000); Costa Leja et al. (2001); González et al. (2013); Heinzl (Heinzl et al. 2013); Kalnins and Jarohnovich (2015); Khaleel Malik (2002); Nilsson (Nilsson et al. 2010); Rubiralta (2004); and Bozeman et al. (2015).

Table 2. List of elements of a TT.

\begin{tabular}{|c|c|c|c|c|c|}
\hline $\begin{array}{l}\text { Transfer } \\
\text { Object }\end{array}$ & $\begin{array}{l}\text { Transfer } \\
\text { Medium }\end{array}$ & TT Mechanism & Modality & TT Process Output & $\begin{array}{l}\text { Stage of Use of } \\
\text { Technology }\end{array}$ \\
\hline \multirow{17}{*}{$\begin{array}{c}\text { Scientific } \\
\text { knowledge } \\
\text { Prototype } \\
\text { Know-how } \\
\text { Process Design } \\
\text { Technological } \\
\text { development }\end{array}$} & \multirow{2}{*}{ Patents } & License & \multirow{8}{*}{ Formal } & $\begin{array}{l}\text { Use of technology with legal } \\
\text { restrictions for use by the market }\end{array}$ & Exploitation \\
\hline & & University Spin-off & & Industry with legal restrictions & $\begin{array}{l}\text { Exploration, validation, } \\
\text { and exploitation }\end{array}$ \\
\hline & \multirow{2}{*}{ Prototype } & License & & $\begin{array}{l}\text { Use of technology with legal } \\
\text { restrictions for use by the market }\end{array}$ & Exploitation \\
\hline & & Contract of sale & & $\begin{array}{l}\text { Use of technology without legal } \\
\text { restrictions for use by the market }\end{array}$ & Exploitation \\
\hline & \multirow{4}{*}{$\begin{array}{l}\text { Investigation } \\
\text { study }\end{array}$} & License & & $\begin{array}{l}\text { Use of technology with legal } \\
\text { restrictions for use by the market }\end{array}$ & $\begin{array}{l}\text { Exploration, validation, } \\
\text { and exploitation }\end{array}$ \\
\hline & & Contract of sale & & $\begin{array}{l}\text { Use of technology without legal } \\
\text { restrictions for use by the market }\end{array}$ & Exploitation \\
\hline & & $\begin{array}{l}\text { Delivery of technology } \\
\text { to industry }\end{array}$ & & $\begin{array}{l}\text { Use of technology with legal } \\
\text { restrictions for use by the market }\end{array}$ & $\begin{array}{l}\text { Validation and } \\
\text { exploitation }\end{array}$ \\
\hline & & University Spin-off & & Industry without legal restrictions & $\begin{array}{c}\text { Validation and } \\
\text { exploitation }\end{array}$ \\
\hline & \multirow{2}{*}{$\begin{array}{l}\text { Conference } \\
\text { Presentation }\end{array}$} & University Spin-off & \multirow{9}{*}{ Informal } & Industry without legal restrictions & $\begin{array}{l}\text { Validation and } \\
\text { exploitation }\end{array}$ \\
\hline & & Knowledge capture & & Transferred knowledge & $\begin{array}{c}\text { Exploration, validation, } \\
\text { and exploitation }\end{array}$ \\
\hline & \multirow{2}{*}{$\begin{array}{c}\text { Paper } \\
\text { publication }\end{array}$} & University Spin-off & & Industry without legal restrictions & $\begin{array}{l}\text { Validation and } \\
\text { exploitation }\end{array}$ \\
\hline & & Knowledge capture & & Transferred knowledge & $\begin{array}{l}\text { Exploration, validation, } \\
\text { and exploitation }\end{array}$ \\
\hline & \multirow{3}{*}{$\begin{array}{l}\text { Movement of } \\
\text { research staff }\end{array}$} & University Spin-off & & Industry without legal restrictions & $\begin{array}{c}\text { Validation and } \\
\text { exploitation }\end{array}$ \\
\hline & & Knowledge capture & & Transferred knowledge & $\begin{array}{l}\text { Exploration, validation, } \\
\text { and exploitation }\end{array}$ \\
\hline & & Recruitment & & Transferred knowledge & $\begin{array}{l}\text { Exploration, validation, } \\
\text { and Exploitation }\end{array}$ \\
\hline & \multirow{2}{*}{$\begin{array}{c}\text { Informal } \\
\text { discussions }\end{array}$} & University Spin-off & & Industry without legal restrictions & $\begin{array}{l}\text { Validation and } \\
\text { exploitation }\end{array}$ \\
\hline & & Knowledge capture & & Transferred knowledge & $\begin{array}{l}\text { Exploration, validation, } \\
\text { and exploitation }\end{array}$ \\
\hline
\end{tabular}

Table 2 also shows a relationship between the output of the transfer process and the state in which the industry can use the technology. It must be described that the possible states of use, in which the industry can use the technology, will depend on the combination of the medium, mechanism and modality. 
Finally, it is necessary to describe the interaction that occurs in the technology transfer process (Figure 5). As described above, this process occurs within the UIC context, in which there are social and political factors that support or impede the TT process and where the collaboration occurs under the mission of a university and an industry. Within the transfer process you can see the linear interaction between the transmitter and receiver; however, the literature review shows that this process carries with it a feedback that helps to improve future TT processes. The transfer process occurs in a medium and that the mechanic serves as a vehicle that transports the technology.

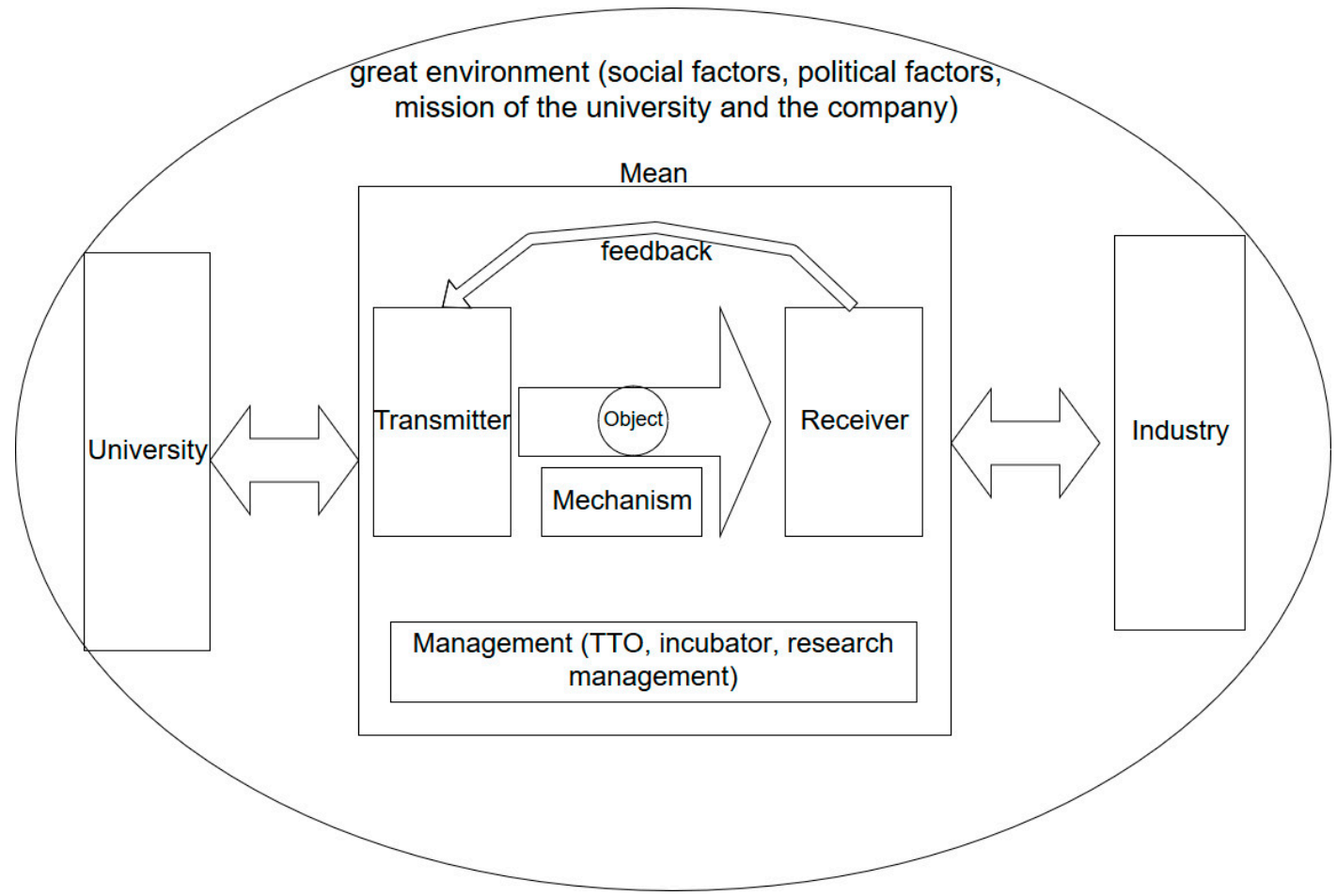

Figure 5. TT conceptual model of university-industry-collaboration (UIC).

\subsection{Complementary Elements for University-Industry Collaboration (UIC) Technology Transfer}

The complementary elements are described as those that appear to adapt the models to real situations. As mentioned above, the transfer model could be described as a linear process such as a broadcast where an agent transmits a message to another. However, the literature describes other agents that may facilitate or impede the transfer process.

\subsubsection{Technological Transfer Office (TTO)}

The centers, which generate knowledge and technology, such as universities, currently have a channel through which the exchange of knowledge and technology has become more effective-this known as the technology transfer office (TTO) (Mascarenhas et al. 2018). This office must be able to find the most appropriate way to transfer the technology; as described above, there are many ways to transfer technology, depending on the social and political context where it is developed (Carrick 2014). In addition, it cannot be thought that the content of a paper is sufficient to transfer a technology, since there are many barriers that prevent a good functioning of the UIC: communication, culture, motivation of stakeholders (Brennan and Turnbull 2002), and political changes (Landry et al. 2013), as well as lack of time on the part of the industry and poor identification of those responsible, among others (Hughes and Kitson 2012). Therefore, it is necessary to have an agent that is exclusively responsible for the UIC (Costa Leja et al. 2001). 
Thus, TTOs have arisen from the need for communication between universities and industries, for the benefit of both. Currently, universities are concerned with creating a marketing culture for their research and are looking for the most efficient TT mechanisms for each situation. In this way, they not only focus on the reputation given by publications and conferences (Khakbaz 2012). This is why there is a need to help researchers market their work (Nilsson et al. 2010) and encourage them to transfer their creations so that they can feel protected (Khakbaz 2012).

A TTO is the axis that facilitates the commercialization of academic research, patent processing, negotiation, and the management of active licenses (Rahmany et al. 2013). Its functions highlight the support to connect researchers with users and graduates who are working across industries (Mowery 2011). This implies that they are the link between universities and industries (Carrick 2014). It should be noted that researchers do not necessarily use TTOs to generate a transfer; in some cases, they have direct contact with the industry (Nilsson et al. 2010).

Thus, the role of the TTO is to seek research with greater potential in the market and commercialize the given technology (Perez et al. 2011), including not only patentable research but also motivated researchers interested in commercializing their research (Khakbaz 2012). TTOs aim to help transfer the technology without harming the researcher (Sætre et al. 2009), as well as to support entrepreneurs in advisory services to help strengthen the industry without undermining the raison d'être of a university, which is teaching (Hughes and Kitson 2012).

In addition, TTOs have a strategic focus where their most important functions are to promote cooperation, support agents with recruitment that allows a correct TT process, carry out monitoring and cultural activities, and seek the good of society with the development of technologies (Pereira Fialho and Alberton de Lima 2005; Perez et al. 2011).

\subsubsection{Policies}

Previously, different agents have been defined that involve TT, but nothing has been explained regarding the environment. In this sense, authors such as Rubiralta (2004), Bozeman (Bozeman 2000; Bozeman et al. 2015), and Malik (2002), among others, have highlighted the legal environment, which is why it is necessary to review what various authors have explained about policies.

The State is creating policies that facilitate the creation of innovation funds to help entrepreneurship and research of technological value. These policies also favor investment by industries (Dai et al. 2005; Shane 2004b) and the promotion of local infrastructure (Sætre et al. 2009) and the networks of external suppliers (Khakbaz 2012). At the same time, this improves the culture of research and entrepreneurship because policies are linked to culture (Botelho and Almeida 2011), as well as contributes to the construction of new skills that are necessary in the interaction between research and its application (Mascarenhas et al. 2018).

Policies are part of the legal framework in which technology transfers take place; not having good policies makes this process difficult. Like TTOs, they are not a determinant in the UIC relationship, but they are important (Mowery 2011). In this context, the State is the main actor regarding the policy of innovation and technological transference between agents such as universities and companies. A clear example is Brazil, where industries are not investing in R\&D or developing patents (Stal and Fujino 2005), so policies are currently being developed that help the UIC relationship generate innovation. In response to state policies, universities are also creating their own (Botelho and Almeida 2011). In short, all policies must be clear so that universities and industries are aware of their functions (Shane 2004b).

In the field of universities, there is also a contribution in the policies. It is known that the decisions of senior managers directly influence the UIC (Okamuro and Nishimura 2013) and that a graduate who wants to sell their technology or start a venture could not last long without the help of a university or industry (Sætre et al. 2009). Therefore, universities are seeking to create more flexible and equitable policies through which industry becomes an ally (Okamuro and Nishimura 2013) without losing one of the university's fundamental objectives: teaching (Carlsson and Fridh 2002). On the other hand, the 
university must create policies that allow efficient access to technology; for example, thinking about the protection of exclusive privileges for long periods is incompatible with the needs of the consuming public and the speed of production (Tocach 2011).

\section{Discussions of Our Finding and a Future Research Agenda}

In this paper, we tried to contribute in two important aspects with a systematic review of the literature. First, we showed the common elements used in a general technology transfer model. That is, the transmitter, receiver, medium and mechanism, and the message. We emphasized that some models recognize the mechanism as a way of transfer, although others do differentiate between the mediums and the mechanism. The medium refers to the presentation of the object to be transferred such as a patent, prototype, or a paper, while the mechanism is the way in which the presentation of the object will be transferred. It is necessary to emphasize that in Table 2 the mediums and mechanisms are classified into two columns.

Furthermore, we found literature on complementary elements in technology transfer, which are important in the transfer process, but are not fundamental requirements for carrying out the process. First, we found information on technology transfer offices, which serve as communication supports between the transmitter and the receiver. In the particular case of the transfer in university-industry collaboration, the role of the office is as an intermediary, as agents have different institutional objectives and each one seeks to comply with the others. Second, we contracted policy information, which has a role as a controller and regulator of the transfer process. These policies are displayed both in the receiver and transmitter and in the "environment where the transfer is made. A clear example of the "environment" is the incentives for the generation of university-industry collaboration promoted by the State.

The second contribution has to do with a conceptual model of technology transfer, presented on a graph and complemented by a table that helped us show all the objects that can be transferred, the modality of the transfer, the output of the process, and the state of the technology to be used after the TT process. The table shows the transfer mode, which serves to differentiate the context in which the technology is transferred. In the literature review, the mode was classified as: (1) formal, which refers to a context controlled by entities related to technology transfer; and (2) informal, which does not have any entity related to the transfer but performs the process. The "TT process output" is another column of Table 2; it describes whether the technology is intended for use with or without legal restrictions, and whether it generates new knowledge or the creation of a venture. The last column of Table 2 shows the state of the technology that has been transferred. We found that technology could not only be transferred in a state of exploitation but could also be transferred in validation and exploration states. The graph shows the interaction of components and the presence of an "environment" that allows optimal interaction between agents. It also shows us that the interaction is not linear; rather, it is a system where the receiving and transmitting agents not only fulfill their roles of transfer, but also learn in the process.

The paper has its limitations due to the selection of keywords that were included and excluded. It is necessary to highlight that IT keywords were included as keywords, while subjects related to agriculture, fisheries, and biomedicine were excluded. Therefore, a greater conceptualization of research on issues of technology transfer was necessary. With respect to a future research agenda, it is necessary to study the informal aspects in the transfer mechanism. As described in the literature, not only can a technology be transferred through a license or contract for research, it can also be transferred through an academic enterprise. Future research could focus on entrepreneurship from the point of view of a technological transfer model. It should be noted that collaboration between universities and industries can generate not only technology for a company, but also the entrepreneurship of some agent of the university It would be interesting to know, through case studies, the technological transfer in the context of university-industry collaboration. 
Finally, the knowledge that this paper contributes can be complemented by topics such as the capacity of absorption, which will help in the understanding of the capacity that an industry has for the technology delivered by the university. Another interesting topic that can be investigated in future research is the level of technology; although this article maps out the object delivered by the university and the level of use of technology, it does not go into detail about the levels of technology that agents have.

\section{Conclusions}

In this SRL, we showed that there was a considerable amount of studies on models and elements of technology transfer. The literature review showed the development of technological transfer models in recent times, as well as the common elements that authors used when defining their models.

This research contributes to the theoretical knowledge of the topics related to technology transfer. First, it will help researchers with new insights about the different elements. Second, the classification and tuning of the literature will help the discussion of the different contexts in which the elements can be identified and can be seen from different perspectives.

Additionally, the literature review has implications in practice. Our literature review can serve as a guide for technology transfer offices as the paper defines the elements and main factors in a technology transfer process. For example, the literature describes different ways of transferring an object created by a transmitter, which were presented as formal and informal mediums. Furthermore, another clear example, which the offices could take into consideration, is that there is no dependence between the transfer mechanisms and the levels of use of the technology. Therefore, the technology could be transferred when it is already in validation, exploitation, or exploration stages.

In the particular case of Latin America, the literature shows a growing interest in topics related to TT, where it can be seen that there are more papers related to TT in the context of collaboration between universities and industries. We also found papers that described the operation of TT, from practical cases regarding patents to academic entrepreneurship.

On the other hand, the description of the models is a fundamental factor, as they help elucidate the process of TT and formalize communications. Thus, on the part of the authors, great effort was made to imply that TT is a process that is affected by the external environment (social, behavioral, and legislative factors). There were also different approaches to correctly define transfer paths. For example, Bozeman (Bozeman 2000; Bozeman et al. 2015) described all types of medium as a mechanism, but Hoffmann (Hoffmann et al. 2009) differentiated the form of transference (mechanism) to university (medium) production, because production can be presented in different ways (patents, conferences, prototypes, etc.), but does not guarantee the transfer. It is possible to conclude that the models presented by Gorschek (Gorschek et al. 2006), Khabiri (Khabiri et al. 2012), and Malik (Malik 2002) had linear processes and formal TT mechanisms, whereas other models presented by Bozeman (2000), Mayer and Blaas (2002), Rubiralta (2004), and Bozeman et al. (2015) presented more systemic models, using mechanisms that may be formal or informal.

Author Contributions: J.J.A. and D.G. designed the methodology of systematic revision of literature. J.J.A. executed the methodology and wrote the results. D.G. reviewed the document.

Conflicts of Interest: The authors declare no conflict of interest.

\section{References}

Agrawal, Ajay, and Iain Cockburn. 2003. The anchor tenant hypothesis: Exploring the role of large, local, R\&D-intensive firms in regional innovation systems. International Journal of Industrial Organization 21: 1227-53.

Anderson, Timothy R., Tugrul U. Daim, and Francois F. Lavoie. 2007. Measuring the efficiency of university technology transfer. Technovation 27: 306-18. [CrossRef] 
Botelho, Antonio Jos Junqueira, and Mariza Almeida. 2011. Overcoming institutional shortcomings for academic spin-off policies in Brazil. The International Journal of Technology Management E Sustainable Development 9: 175-93.

Bozeman, Barry. 2000. Technology transfer and public policy: A review of research and theory. Research Policy 29: 627-55. [CrossRef]

Bozeman, Barry, Heather Rimes, and Jan Youtie. 2015. The evolving state-of-the-art in technology transfer research: Revisiting the contingent effectiveness model. Research Policy 44: 34-49. [CrossRef]

Brennan, Ross, and Peter W. Turnbull. 2002. Sophistry, relevance and technology transfer in management research: An IMP perspective. Journal of Business Research 55: 595-602. [CrossRef]

Burnside, Beth, and Lou Witkin. 2008. Forging Successful University-Industry Collaborations. Research Technology Management 51: 26-30. [CrossRef]

Carlsson, Bo, and Ann-Charlotte Fridh. 2002. Technology transfer in United States universities-A survey and statistical analysis. Journal of Evolutionary Economics 12: 199-232. [CrossRef]

Carrick, Jon. 2014. Technology Based Academic Entrepreneurship: How Little We Know. Journal of Strategic Innovation and Sustainability 9: 63-75.

Choi, Hee Jun. 2009. Technology Transfer Issues and a New Technology Transfer Model. Journal of Technology Studies 35: 49-57. [CrossRef]

Cohen, Wesley M., Richard R. Nelson, and John P. Walsh. 2002. Links and Impacts: The Influence of Public Research on Industrial R\&D. Management Science 48: 1-23. [CrossRef]

Costa Leja, C., M. Gelonch, C. Badía Roig, and F. Juárez Rubio. 2001. Los Centros de Transferencia de Tecnología Universitarios: Organización y Financiación. San José: Asociación Latino-Iberoamericana de Gestión Tecnológica.

Cunningham, James A., Matthias Menter, and Chris Young. 2017. A review of qualitative case methods trends and themes used in technology transfer research. Journal of Technology Transfer 42: 923-56. [CrossRef]

Dai, Yixin, David Popp, and Stuart Bretschneider. 2005. Institutions and intellectual property: The influence of institutional forces on university patenting. Journal of Policy Analysis and Management 24: 579-98. [CrossRef]

Dalmarco, Gustavo, Paulo Antônio Zawislak, Willem Hulsink, and Flávio Brambilla. 2015. How knowledge flows in university-industry relations. European Business Review 27: 148-60. [CrossRef]

Djokovic, Djordje, and Vangelis Souitaris. 2008. Spinouts from academic institutions: A literature review with suggestions for further research. Journal of Technology Transfer 33: 225-47. [CrossRef]

Dutrénit, Gabriela, Claudia De Fuentes, and Arturo Torres. 2010. Channels of interaction between public research organisations and industry and their benefits: Evidence from Mexico. Science and Public Policy 37: 513-26. [CrossRef]

Etzkowitz, Henry. 2000. Tech transfer, incubators probed at Triple Helix III. Research Technology Management 43: $4-5$.

Fialho, Francisco Antonio, and Isaura Alberton de Lima. 2001. A Cooperação Universidade-Empresa como Instrumento de Desenvolvimento Tecnologico. San José: Asociación Latino-Iberoamericana de Gestión Tecnológica.

Galbraith, Craig S., Sanford B. Ehrlich, and Alex F. DeNoble. 2006. Predicting Technology Success: Identifying Key Predictors and Assessing Expert Evaluation for Advanced Technologies. Journal of Technology Transfer 31: 673-84. [CrossRef]

González, D., E. Díaz, and M. Guevara. 2013. Explorando las interacciones en los procesos de tecnología en la Universidad. Paper presented at the XV Congreso Latino-Iberoamericano de Gestión Tecnológica, Oporto, Portugal, 29-31 October; pp. 6247-59.

Gorschek, Tony, Per Garre, Stig Larsson, and Claes Wohlin. 2006. A Model for Technology Transfer in Practice. IEEE Software 23: 88-95. [CrossRef]

Grimaldi, Rosa, Martin Kenney, Donald S. Siegel, and Mike Wright. 2011. 30 years after Bayh-Dole: Reassessing academic entrepreneurship. Research Policy 40: 1045-57. [CrossRef]

Grimpe, Christoph, and Heide Fier. 2010. Informal university technology transfer: A comparison between the United States and Germany. The Journal of Technology Transfer 35: 637-50. [CrossRef]

Heinzl, Joachim, Ah-Lian Kor, Graham Orange, and Hans Rüdiger Kaufmann. 2013. Technology transfer model for Austrian higher education institutions. Journal of Technology Transfer 38: 607-40. [CrossRef]

Heslop, Louise A., Eileen McGregor, and May Griffith. 2001. Development of a Technology Readiness Assessment Measure: The Cloverleaf Model of Technology Transfer. Journal of Technology Transfer 26: 369-84. [CrossRef] 
Hoffmann, M. G., M. A. Amal, and I. Mais. 2009. Um Modelo Integrado de Transferência de Tecnologia com Vistas à Inovação-A Experiência da Universidade Regional de Blumenau. San José: Asociación Latino-Iberoamericana de Gestión Tecnológica.

Hughes, Alan, and Michael Kitson. 2012. Pathways to impact and the strategic role of universities: New evidence on the breadth and depth of university knowledge exchange in the UK and the factors constraining its development. Cambridge Journal of Economics 36: 723-50. [CrossRef]

Kalnins, Habil Juris-Roberts, and Natalja Jarohnovich. 2015. System Thinking Approach in Solving Problems of Technology Transfer Process. Procedia Social and Behavioral Sciences 195: 783-89. [CrossRef]

Khabiri, Navid, Sadegh Rast, and Aslan Amat Senin. 2012. Identifying Main Influential Elements in Technology Transfer Process: A Conceptual Model. Procedia Social and Behavioral Sciences 40: 417-23. [CrossRef]

Khakbaz, Peyman Pournasr. 2012. The Role of Research and Development in Growth of Small and Medium Enterprise in Technological Cluster of Regions. Information Management and Business Review 4: 234-41.

Klofsten, Magnus, Peter Heydebreck, and Dylan Jones-Evans. 2010. Transferring good practice beyond organizational borders: Lessons from transferring an entrepreneurship programme. Regional Studies 44: 791-99. [CrossRef]

Lai, Wen-Hsiang. 2011. Willingness-to-engage in technology transfer in industry-university collaborations. Journal of Business Research 64: 1218-23. [CrossRef]

Landau, Herbert B., Jerome T. Maddock, F. Floyd Shoemaker, and Joseph G. Costello. 1982. An information transfer to Define Information Users and Outputs with Specific Application to Environmental Technology. Journal of the American Society for Information Science (Pre-1986) 33: 82-91. [CrossRef]

Landry, Réjean, and Nabil Amara. 2012. Elucidation and enhancement of knowledge and technology transfer business models. The Journal of Information and Knowledge Management Systems 42: 94-116. [CrossRef]

Landry, Réjean, Nabil Amara, Jean-Samuel Cloutier, and Norrin Halilem. 2013. Technology transfer organizations: Services and business models. Technovation 33: 431-49. [CrossRef]

Lulu, M., G. Seyoum, and F. W. Swift. 1996. A decision model for technology transfer. Computers E Industrial Engineering 31: 37-40. [CrossRef]

Malik, Khaleel. 2002. Aiding the technology manager: A conceptual model for intra-firm technology transfer. Technovation 22: 427-36. [CrossRef]

Mascarenhas, Carla, João J. Ferreira, and Carla Marques. 2018. University-industry cooperation: A systematic literature review and research agenda. Science and Public Policy, 1-11. [CrossRef]

Mayer, Sabine, and Wolfgang Blaas. 2002. Technology Transfer: An Opportunity for Small Open Economies. Journal of Technology Transfer 27: 275-89. [CrossRef]

Mesquita, Anabela, and Tudorel Popescu. 2014. Universities in the business environment. Faima Business $\mathcal{E}$ Management Journal 2: 5-13.

Miller, Kristel, Rodney McAdam, and Maura McAdam. 2016. A systematic literature review of university technology transfer from a quadruple helix perspective: Toward a research agenda. RED Management, 7-24. [CrossRef]

Mowery, David C. 2011. Learning from one another? International policy "emulation" and university-industry technology transfer. Industrial and Corporate Change 20: 1827-53. [CrossRef]

Nilsson, Anna S., Annika Rickne, and Lars Bengtsson. 2010. Transfer of academic research: Uncovering the grey zone. Journal of Technology Transfer 35: 617-36. [CrossRef]

Ohara, Yoshio. 1981. Japanese Regulation of Technology Imports. Journal of World Trade Law 15: 83-90.

Okamuro, Hiroyuki, and Junichi Nishimura. 2013. Impact of university intellectual property policy on the performance of university-industry research collaboration. Journal of Technology Transfer 38: $273-301$. [CrossRef]

Pereira Fialho, F. A., and Isaura Alberton de Lima. 2005. Estrutura de Referência para Transferência de Tecnologia no Âmbido da Cooperação Universidade-Empresa. Salvador: Asociación Latino-Iberoamericana de Gestión Tecnológica, pp. 1-10.

Perez, P., G. Gonzalez Gonzalez, O. Suchil, J. Hernandez, and A. Nunez Merchand. 2011. El Instituto Politécnico Nacional y los Dilemas de la Transferencia de Tecnología en las Universidades Mexicanas. Lima: Asociación Latino-Iberoamericana de Gestión Tecnológica, vol. XIV, pp. 81-87. [CrossRef] 
Perkmann, Markus, Valentina Tartari, Maureen McKelvey, Erkko Autio, Anders Broström, Pablo D’Este, and Riccardo Fini. 2013. Academic engagement and commercialisation: A review of the literature on university-industry relations. Research Policy 42: 423-42. [CrossRef]

Purushotham, H., V. Sridhar, and Ch Shyam Sunder. 2013. Management of Technology Transfer from Indian Publicly Funded R\&D Institutions to Industry-Modeling of Factors Impacting Successful Technology Transfer. International Journal of Innovation, Management and Technology 4: 422. [CrossRef]

Rahal, Ahmad D., and Luis C. Rabelo. 2006. Assessment Framework for the Evaluation and Prioritization of University Inventions for Licensing and Commercialization. Engineering Management Journal 18: 28-36. [CrossRef]

Rahmany, Maria B., Bill J. Tawil, Kiki B. Hellman, Peter C. Johnson, Mark Van Dyke, and Tim Bertram. 2013. Bench to Business: A Framework to Assess Technology Readiness. Tissue Engineering Part A 19: 2314-17. [CrossRef] [PubMed]

Etzkowitz, Henry, and Marina Ranga. 2013. Triple Helix systems: An analytical framework for innovation policy and practice in the Knowledge Society. Industry and Higher Education. Entrepreneurship and Knowledge Exchange 27: 117-58. [CrossRef]

Rothaermel, Frank T., Shanti D. Agung, and Lin Jiang. 2007. University entrepreneurship: A taxonomy of the literature. Industrial and Corporate Change 16: 691-791. [CrossRef]

Rubiralta, Mariano. 2004. Transferencia a las Empresas de la Investigación Universitaria. Salzburgo: Academia Europea de Ciencias y Artes.

Sábato, Jorge, and Natalio Botana. 1968. La ciencia y la tecnología en el desarrollo futuro de América Latina. Revista de La Integración 3: 15-36.

Sætre, Alf Steinar, Joel Wiggins, Ola Thomas Atkinson, and Beate Kristin Ellerås Atkinson. 2009. University Spin-Offs as Technology Transfer: A Comparative Study among Norway, the United States, and Sweden. Comparative Technology Transfer and Society 7: 115-45. [CrossRef]

Shane, Scott Andrew. 2004a. Cademic Entrepreneurship: University Spinoffs and Wealth Creation. Cheltenham: Edward Elgar Publishing Ltd.

Shane, Scott Andrew. 2004b. Encouraging university entreprenuership? The effect of the Bayh-Dole Act on university patenting in the United States. Journal of Business Venturing 19: 127-51. [CrossRef]

Siegel, Donald S., David A. Waldman, Leanne E. Atwater, and Albert N. Link. 2004. Toward a model of the effective transfer of scientific knowledge from academicians to practitioners: Qualitative evidence from the commercialization of university technologies. Journal of Engineering and Technology Management 21: 115-42. [CrossRef]

Siegel, Donald S., David Waldman, and Albert Link. 2003. Assessing the impact of organizational practices on the relative productivity of university technology transfer offices: An exploratory study. Research Policy 32: 27-48. [CrossRef]

Smits, William H., Jr. 1984. Transfer of High Technology from the United States to the Soviet Bloc: A Public Policy Issue. International Journal of Public Administration 6: 245-77. [CrossRef]

Spencer, William J. 1990. Research to Product: A Major U.S. Challenge. California Management Review 32: 45-53. [CrossRef]

Stal, E., and A. Fujino. 2005. Aprimorando as Relações Universidade-Empresa-Governo no Brasil: A Lei de Inovação e a Gestão da Propriedade Intelectual. Salvador: Asociación Latino-lberoamericana de Gestión Tecnológica, pp. 1-14.

Tocach, R. 2011. Transferência de tecnologia na América Latina: Superação da Utopia? Lima: Asociación Latino-Iberoamericana de Gestión Tecnológica.

Tranfield, David, David Denyer, and Palminder Smart. 2003. Towards a Methodology for Developing Evidence-Informed Management Knowledge by Means of Systematic Review. British Journal of Management 14: 207-22. [CrossRef]

Van den Berghe, Larry, and Paul D. Guild. 2008. The strategic value of new university technology and its impact on exclusivity of licensing transactions: An empirical study. Journal of Technology Transfer 33: 91-103. [CrossRef]

Vick, Thais Elaine, and Maxine Robertson. 2017. A systematic literature review of UK university-industry collaboration for knowledge transfer: A future research agenda. Science and Public Policy, 1-12. [CrossRef]

Waroonkun, Tanut, and Rodney Anthony Stewart. 2008. Modeling the international technology transfer process in construction projects: Evidence from Thailand. Journal of Technology Transfer 33: 667-87. [CrossRef]

(C) 2018 by the authors. Licensee MDPI, Basel, Switzerland. This article is an open access article distributed under the terms and conditions of the Creative Commons Attribution (CC BY) license (http://creativecommons.org/licenses/by/4.0/). 